\title{
Determinants of consumer adoption of online air ticketing in Ghana
}

\author{
Kwadwo Asante $^{\mathrm{a}^{*}}$ and Angela Konadu Achiaa ${ }^{a}$
}

${ }^{a}$ SAK Research, Ghana

\section{H R O N I C L E}

Article history:

Received: April 23, 2018

Received in revised format: June

24, 2018

Accepted: August 9, 2018

Available online:

August 9, 2018

Keywords:

Online air ticketing

Airline passengers

Domestic travelers

Ghanaian consumers

\begin{abstract}
A B S T R A C T
The study investigated the factors that attract consumers to adopt online air ticketing within the Ghanaian context. The study followed the positivist paradigm approach hence, quantitative methodology was adopted. The total population for the study covered passengers of Africa World airline, Antrak air, Fly 540 and Starbow airline. The target population for this study consisted of all the customers in these institutions that have in one way or the other purchased or booked their flight ticket on the website. Stratified random sampling was used in the first stage to ensure that all subgroups were fairly represented. The study employed purposive sampling and afterwards the study used the Krejcie and Morgan sampling table to determine the sample size for the 250 population size. Based on the table, the sample size for the study employed was 152 . Since the study was guided on the principles of quantitative methodology, this study used questionnaires on a 5 point Likert scale for the study. The study distributed 152 questionnaires to passengers of the selected airline companies within the Kumasi metropolis in the Ashanti region. From the questionnaires distributed, a total of 89 completed questionnaires were returned to the researchers. Of these, 79 were usable for analysis, giving an effective response rate of $55.6 \%$. Data was subsequently analysed using descriptive statistics such as mean and standard deviation. Inferential statistics included Pearson correlation, multiple regression (enter method) were used for the relationship analysis. Findings from the study showed that the variables that had the significant impact on respondents' decision to adopt online air ticketing were; trust, attitude, perceived risk and internet knowledge. The study recommended that the managers of these airlines companies should work on their reputation in order to position themselves as trustworthy airlines companies since consumer's decision to use their online platforms to purchase their ticket was informed by how the consumer perceived the entities offering to be dependable and secured.
\end{abstract}

C 2018 by the authors; licensee Growing Science, Canada

\section{Introduction}

Airline electronic commerce market is one of the fast growing industries in the world. Airline industry's ticket distribution channel is changing to e-ticketing. This distribution channel gives customers the ability to purchase e-ticket quickly and it has a cost saving benefits for both the company and the customers as well (Chen, 2007). Even though virtual distributors on the internet have raised concerns on issues such as; security and trust, but still e-ticketing has proven to be one of the most important channels for airlines

* Corresponding author. Tel.: 233249338732

E-mail address: samuelkwadwoasante@gmail.com (K. Asante)

(C) 2018 by the authors; licensee Growing Science, Canada doi: $10.5267 /$ j.msl.2018.8.003 
to sell tickets (Motlaq et al., 2012). Moreover, statistics presented by Internet World Statistics (2014) indicate that in the year 2012 alone, there were over 2405 million users of internet worldwide which per this estimates suggest that $34.3 \%$ of the total world population have access to internet facility. Likewise within the Ghanaian context, figures available show that in the last quarter of 2017, the total number of mobile data subscription stood at 22,865,821 with a penetration rate at $79.94 \%$ (Ghana Communication Authority, 2017). This suggests that the total number of data subscription in Ghana takes up $78.2 \%$ of the total population of Ghana meaning $78.2 \%$ of the Ghanaian population have access to internet via their mobile phones. Accordingly, this upsurge in data subscription among Ghanaian consumers has provided a new opportunity for several businesses to incorporate additional marketing channels through e-marketing platforms to complement the traditional marketing and distribution channels within the country. Hence, the recent proliferation of the Ghanaian marketing landscape with online marketing platforms such as; Tonaton.com, OLX.com, jobs-in-ghana.com, jobberman.com, carmudi.com.gh, etc. affirms the recent transition to an e-platform (Ajzen, 1991).

The new era of information technology has brought multiple advantages to the mankind. In particular, the internet allowed us to search for goods in stores right from our apartments and find best offers in several clicks. Moreover, more and more people all over the world prefer to shop online and order all kinds of products on different websites. Apart from consumer goods sales and e-tailing, online travelling sector has been booming in recent years and the number of users booking their vacations on the Web has been steadily growing (Bychkov, 2014). Historically, air tickets sales represented a big part of the travel industry and their share is even more significant when talking about online travelling. For instance, according to a forecast by the International Air Transport Association, (2013) (IATA), the annual number of airline passengers worldwide will reach 3.3 billion in 2014, which makes it approximately 9 million people holding an air ticket and boarding a plane every day all over the world. Over the last few years, digital environment has significantly shaped the relationship between primary ticket sellers, i.e. airlines, intermediaries (e.g. travel agencies or other ticket resellers) and their customers (air passengers).

According to Kaplan and Haenlein (2012) the ability of online platforms to connect businesses directly to end-consumers, in a timely fashion and at a lower cost has being viewed as a greater leveler to both the industry and consumers in general. This has triggered many companies today to have pages on online platforms to supplement their traditional distribution channels. Besides, consumers have the tendency to relate much more with a company after they read various reviews and comments of other consumers who have already purchased from or used these platforms. Bukhari et al. (2012) posit that despite the widespread discussions of online platforms on consumer buying decisions, there is still a lack of research in the area of its impact on consumer buying decision of air ticketing in developing countries thus, using the internet for different purposes and buying specific kind of products (e-tickets). Although, airline passengers' buying behaviour has been looked at by different authors such as; Diggines (2010), Gupta et al. (2004) and $\mathrm{Yu}(2008)$ nonetheless all these stated works primarily focused on Anglo-American and Asian countries with no emphasis on sub-Saharan African consumers. Hence, this study address this gap by measuring factors that attract consumers to buy air ticketing online in a non-Anglo American context therefore, contributing to the limited literature in the sub-Saharan African context. Therefore the main aim of the study is to understand factors that attract consumers to adopt online air ticketing within the Kumasi metropolis.

\section{Literature Review}

\subsection{Theoretical Review}

One of the well-known models related to technology acceptance and usage is the technology acceptance model (TAM) originally proposed by Davis in 1989. TAM has proven to be one of the key theoretical models used to explain and predict user behaviour of information technology (Legris, et al., 2003). According to Ajzen and Fishbein (1980) TAM is considered as an influential extension of theory of reasoned 
action (TRA). Davis (1989) and Davis et al. (1989) proposed TAM to explain why a user accepts or rejects information technology by adapting the principles of TRA. TAM provides a basis with which one traces how external variables influence a person belief, attitude, and intention to use. Two cognitive beliefs are posited by TAM thus, the perceived usefulness and perceived ease of use. Like TRA, TAM postulates that actual technology usage is determined by behavioural intent (BI). The perceived usefulness (PU) is based on the assumption that "people tend to use or not use an application to the extent that they believe it will help them perform their job better" (Davis, 1989, p. 320). PU directly influences the attitude toward use of the system and indirectly influences behavioural intention to use. Even if an application is perceived as useful, it will only be used if it is seen by the user as easy to use (PEOU), that is, benefits of usage outweigh the effort of using the system. The perceived usefulness (PU) is based on the assumption that "people tend to use or not use an application to the extent they believe it will help them perform their job better" (Davis, 1989, p. 320). PU directly influences the attitude toward use of the system and indirectly influences behavioural intention to use. However, it is observed that even when an application is seen to be useful, it will only be used if it is perceived as easy to use (PEOU), that is, benefits of usage outweigh the effort of using the system. Similarly, users' positive attitude toward a specific technology leads them developing an intention to use this technology. TAM suggests that users' behavioural intention (BI) shapes their actual use of the technology (AU). If users have intention to use a specific technology then they use it. Therefore, the present study will be interested in investigating how the technology acceptance model is able to predict Ghanaian consumers' decision or intention to adopt air ticketing online.

\subsubsection{Online consumer behaviour}

Understanding customers' motives, stimuli and incentives, which drive their purchase decision, is a corner stone of success on the market and thus is one of the main goals of marketing analysts. In order to understand customers' behaviour the Five-Stage model of buying decision process has been developed. This model disaggregates the process of purchasing into 5 steps, namely, problem recognition, information search, and evaluation of alternatives, purchase decision and post purchase behaviour (Kotler \& Keller, 2009). Kotler and Keller (2009) opined that when buying a product, an individual will not necessarily pass through all the five stages of the buying processes. Hence, depending on the complexity and availability of the product as well as on the proficiency and exactingness of a particular consumer, one or several steps may be skipped. Moreover, in each stage actual behaviour of a buyer is determined by several factors. Due to different cultural and social backgrounds, personal traits, motives and attitudes, different consumers have distinct needs that are triggered by different circumstances. This is why consumers search for the information with different thoroughness and intensity, pay attention to various attributes of the desired product and take into account their specific preferences in the purchase decision process and post purchase behaviour. However, the advent of information technology has significantly influenced the above described process. Hence, it has made some steps easier and has given additional advantages to buyers by providing unlimited access to the information and reducing their transaction costs, nonetheless, it seems to has added new forms of risk and uncertainty in some of the buying processes too (Muller, et al., 2011).

\subsubsection{Factors that consumer's decision to adopt e-ticketing}

Many scholars have endeavored to assess the importance and contribution of various factors that impact on consumers' attitudes towards online purchasing. For instance, per the studies of Li and Zhang (2002) and that of Guo and Jaafar (2011), it was established that factors such as: website quality and perceived usability, security and privacy on the internet, vendor's credibility and reputation as well as product characteristics and after sale services were the key factors that influenced consumers' decisions to purchase online. More so, works by Ho and Lee (2007), Mills and Morrison (2003), Shchiglik and Barnes (2004), Nusair and Kandampully (2008) and that of Kwek et al. (2010) which sought to identify factors that attract consumers to purchase air ticket online came to the conclusion that factors such as; ease of 
use, usability, trust, responsiveness, information quality, availability, interactivity, enjoyment, personalization, customer service and compensation were the main factors that predicted consumers' usage of the online platform for the purchase of the airline ticket.

Again, it has been postulated that factors such as; web site quality, security, responsiveness and information quality are the key variables that influence consumers' decision to purchase their air ticket electronically in Saudi Arabia (Bukhari, et al., 2012). On another breadth, Kim et al. (2005) and Kim et al. (2009) focused on one of the factors influencing travellers' behaviour in purchasing airline tickets on the Internet thus, perceived risk. Initially, the correlation between different dimensions of risk was established and their impact on customers' willingness to buy air tickets online was analysed (Kim, et al., 2005). However, it was revealed that the risk associated with electronic purchases was the main factor that shaped consumers' decision to purchase air-ticket online. Finally, a more practical study that came to notice was the work undertaken by Toh et al. (2011). The surveys were conducted in order to examine passengers' perception of online air ticket sales as well as factors affecting their actual behaviour when making choices and buying air tickets on the Web. Several findings of this paper deserve enumeration due to their similarity to this study. First and foremost, the role of the internet as a dominating channel to search flights and favourable attitude of passengers towards online travel agents were established (Toh, et al., 2012, p. 83). Besides, it became evident that, logically, leisure travellers were more likely to book air tickets on the web than business travellers, who most of the time rely on third parties to purchase their tickets (Toh et al., 2012, p. 84). Expectedly, lower fares were posited to be one of the main motives driving passengers' behaviour to book their ticket online. This explains the transactional value creation as espoused earlier by Beldona et al. (2005) where consumers or buyers in an attempt to get much value (i.e. cheaper tickets) use the internet as a tool for comparing flights fares. Intriguingly, women were found out to be much more aggressive low price seekers rather than their counterparts, men.

\section{Methods}

This study employed a cross-sectional research design to examine factors that attract consumers to buy air ticketing online within the Kumasi metropolis. The target population for this study constituted airline passengers in Ghana who travel domestically or used domestic airlines. Hence, upon this qualification the target population was passengers of Africa World airline, Antrak air, Fly 540 and Starbow airline because they were the only domestic carriers that were available at the time of this research. Accordingly, a projected number of 250 customers of these four airline carriers were targeted as the study population. Moreover, in order to make the sample representative of the entire population the study used the Krejcie and Morgan (1970) sampling table to determine the sample size for the 250 participants for the population size. Based on the table, the sample size for this study employed was 152 with $95 \%$ confidence level with $5.0 \%$ confidence interval (i.e. \pm 5 per cent). The study used the main constructs in the TAM together with other factors identified in the literature to influence users' decision to use a technology or to adopt a new system to measure how these factors may predict consumers decision to purchase online air ticketing within the Ghanaian context. Hence, the main items used in the study were; perceived risk, trust, perceived usefulness, website quality, price perception, attitude, ease of use and internet. On these items, the study used a five-point scale rating thus, 1-strongly disagree to 5-strongly agree to elicit the respondents' responses as to how these factors may influence their decision to purchase their air ticket electronically or not. The study used questionnaire items for the data collection. The administration of the questionnaire was done by the researchers and one field assistant who equally assisted the researcher in the data collection exercise. Both the researcher and her assistant visited the Kumasi airport and the offices of all the four airlines companies on five consecutive occasions. Prior permission was sought from the all the respondents before the questionnaires were eventually given to them to respond to. Multiple linear regression analysis was used for the determinant analysis. The study distributed 152 questionnaires to

passengers of some selected airline companies (i.e. Africa World airline, Antrak air, Fly 540 and Starbow airline) within the Kumasi metropolis in the Ashanti region. From the questionnaires distributed, a total 
of 89 completed questionnaires were returned to the researcher. Of these, 79 were usable for analysis, giving an effective response rate of $55.6 \%$.

\section{Results}

The descriptive statistics about the demographic profile of the respondents are presented in Table 1.

Table 1

Demographic Profile of the Respondents

\begin{tabular}{|c|c|c|c|}
\hline Demographic variable & Category & Frequency & Percentage \\
\hline \multirow[t]{2}{*}{ Gender } & Male & 50 & $63.3 \%$ \\
\hline & Female & 29 & $36.7 \%$ \\
\hline \multirow[t]{3}{*}{ Age } & $25-35$ years & 32 & $40.5 \%$ \\
\hline & $36-45$ years & 39 & $49.5 \%$ \\
\hline & $46-55$ years & 8 & $10.1 \%$ \\
\hline \multirow[t]{5}{*}{ Education } & WASSCE/SSCE & 16 & $20.3 \%$ \\
\hline & Technical/Vocational & 16 & $20.3 \%$ \\
\hline & Diploma/HND & 16 & $20.3 \%$ \\
\hline & Bachelor's degree & 16 & $20.3 \%$ \\
\hline & Master's degree & 15 & $19.0 \%$ \\
\hline \multirow[t]{2}{*}{ Years of air travelling } & Less than 1 year & 35 & $44.3 \%$ \\
\hline & $1-5$ years & 44 & $55.7 \%$ \\
\hline \multirow[t]{4}{*}{ Airline normally used } & Starbow & 20 & $25.3 \%$ \\
\hline & Antrak Air & 18 & $22.8 \%$ \\
\hline & Fly 540 & 16 & $20.3 \%$ \\
\hline & African World Airline & 25 & $31.6 \%$ \\
\hline
\end{tabular}

Source: Author's fieldwork, 2018.

Results from the demographic profile revealed that most of the respondents' ages fell within the age bracket of 25-45 years. Also, with reference to the respondents' gender status, more than half of the respondents were males. However, for the respondents' educational background, an equal half of the respondents either had a WASSCE/SSCE, Technical/Vocational, Diploma/HND and bachelor's degree as their academic qualifications. Also, the results from the study suggest that almost all the respondents had travelled via air within the last 1-5 years. Finally, results from the demographic characteristics suggest that most of the respondents used African World Airline of Starbow for their domestic air travelling.

\subsection{Regression analysis of factors influencing consumer adoption of air ticketing}

The regression analysis of the factors that may influenced the respondents' decision to adopt online air ticketing is presented in Table 2.

\section{Table 2}

Relationship between explanatory variables and adoption of air ticketing

\begin{tabular}{|c|c|c|c|c|c|}
\hline Variables & $\begin{array}{l}\text { Unstandardized co- } \\
\text { efficient }\end{array}$ & Standard error & R Square & $\begin{array}{l}\text { Adjusted } \quad \mathrm{R} \\
\text { square }\end{array}$ & $\begin{array}{l}\text { Significance } \\
\text { level }\end{array}$ \\
\hline Constant & 16.642 & 3.160 & .378 & .306 & .000 \\
\hline Trus. & -.429 & .214 & & & .049 \\
\hline Perceived. use & .281 & .254 & & & .272 \\
\hline Website. qual & .427 & .250 & & & .092 \\
\hline Price. perception & .016 & .054 & & & .775 \\
\hline Att. & .341 & .138 & & & .016 \\
\hline Ease. use & -.241 & .124 & & & .056 \\
\hline Perceived. risk & -.652 & .162 & & & .000 \\
\hline Internet. Knowledge & -.435 & .196 & & & .030 \\
\hline
\end{tabular}


The multiple regression results in Table 2 reveal that trust had a significant negative impact on respondents intension to use or adopt online airline $p<0.05$. This means as trust issues decrease respondents intention to use online air ticketing will increase concurrently by 0.429 . On this score the alternative hypothesis which suggested trust quality positively influences the intention to purchase airline tickets online is rejected and the null hypothesis is accepted. Also, it became evident that there was no significant impact between perceived usefulness and intention to use online air ticketing since $p>0.05$. Hence, the alternative hypothesis which assumed that perceived usefulness will positively influence the intention to purchase airline tickets online is likewise rejected. Evidence from the study established that there is no significant impact between website quality and respondents intention to adopt online air ticketing since $p>0.05$. Therefore, the alternative hypothesis which suggested that website quality positively influences the intention to purchase airline tickets online is rejected. Equally, it was established that there is no significant impact between price perception, ease of use and respondents intention to adopt online air ticketing since $p>0.05$. On this note, the alternative hypotheses which assumed that price perception and ease of use will positively influence the intention to purchase airline tickets online are rejected concurrently. However, it became evident that a respondent attitude, perceived risk and respondent internet knowledge had significant impacts on respondents' decision to adopt online air ticketing since $\mathrm{p}<0.05$. Hence, the alternative hypothesis which suggested that attitude positively influences the intention to purchase airline tickets online is accepted. In contrast, the hypotheses which suggested that perceived risk and internet knowledge positively influence the intention to purchase airline tickets online are rejected since the coefficient values for the two were -0.652 and -0.435 , respectively thus, all had negative values. This means as perceived risk decreases respondents' intentions to use online air ticketing will increase in the opposite direction by 0.652 concurrently. Findings from this study suggest that the variables that had the most significant impact on respondents' decision to adopt online air ticketing were; trust, attitude, perceived risk and internet knowledge. However, perceived use, website quality, price perception and ease of use did not have any significant impact on respondents' decision to adopt online air ticketing.

\section{Discussions}

Findings from this work suggests, factors such as; perceived usefulness, website quality, price perception and ease of use of an online air ticketing were not likely to influence the respondents decision to purchase their air ticket on online platforms. This revelation suggests that the respondents did not necessarily view online air ticketing to have any beneficial appeal to benefit its users. This is quite revealing since the literature largely suggests online platforms are quite convenient and helpful to consumers than traditional channels. This inconsistency could largely attribute to most Ghanaians consumers preference to still purchase their products and services physically mainly because they believe most firms or sellers cannot be trusted to deliver goods and services at the specified quality without the physical presence of the buyer. Also, the inability of the price perception to influence the respondents' decision to purchase their air ticket online could somehow be linked to non-existence of price differentials in items and services purchase either via an online platform or at a physical location. In Ghana it is most interesting to note that most sellers and retailers do not give discount or lower price for goods bought online. Per this happenings buyers with the great preference to buy their goods at a physical location with the intent to examine the product prior to purchase may not see the usefulness to purchase their products online since there is no price differentials between goods purchased online or at physical location. Accordingly, findings from this study are consistent with the results of Kim et al. (2005) and Kim et al. (2009) which confirmed respondents' internet knowledge and perceived risk as the key factors that influence consumers' decision to adopt or purchase online air ticketing. Again, findings from this study confirms the earlier works of Sam and Tahir (2009) which identified perceived risk as one of the antecedents that influence consumer decision to adopt online air ticketing. On the other hand, results of the study rejects the views of Sam and Tahir (2009) which asserted that website quality influence consumer decision to adopt online air ticketing. Also, findings from this study rejects the views of Bukhari et al. (2012) which posited that website quality and price perception have a significant impact on a person decision to adopt online air ticketing. Finally, findings of this study could not affirm the works of Llach et al. (2013) which identified price 
perception of online air ticketing as the one of the factors that influences consumer's decision to adopt online air ticketing.

\section{Conclusions}

Results from the study have suggested that consumers would only see the need to use online platforms for their shopping decisions or transactions when they viewed the benefits to be very evident in their daily dealings hence, when an online platforms promises to provide a certain benefits and fails to provide that users or to the targeted user he/she may not be enthused or motivated to use it. Also, key issues such as; trust, a person's attitude, perceived risk and internet knowledge were the factors found to likely to influence consumers decisions to adopt or use online air ticketing within the Ghanaian context. This suggests that before an individual adopts online air ticketing that person will ascertain whether the vender or the agent is trust worthy likewise, the person owns attributes has to commensurate with its usage and also a person has to view the platform to be risk free and finally the person's ability to use the internet will equally affect their intention to adopt or purchase an air ticket online.

\section{Limitations and Further Studies}

Findings from this study used only eight factors to ascertain how these factors may influence consumers decision to adopt online air ticketing, therefore its findings may not be exhaustive to cover all the various factors likely to influence buyers' decisions to purchase their product online or use an electronic platforms for their buying decisions hence, over generalization of findings of this study should be used with much care. Again, this study confined itself to the domestic airline users within the Kumasi metropolis therefore, its findings may not be a true reflection of what happens at the other air users within the country specifically the international airlines. Finally, this study confined itself to local airlines hence, a comparative study should be carried out to compare whether the findings also apply to international airlines in Ghana as well in order to validate whether the findings can be generalized to all airlines companies in Ghana. Also, other study variables such as respondents' income level, position within their work organization and educational level did not form part of the moderating variables to ascertain how these variables affect an individual decision to adopt online air ticketing. Hence, other studies should employ these variables to measure how they affect a person decision to adopt online air ticketing.

\section{References}

Ajzen, I. (1991). The theory of planned behavior. Organizational behavior and human decision processes, 50(2), 179-211.

Ajzen, I. \& Fishbein, M. (1980). Understanding attitudes and predicting social behavior. Englewood Cliffs, NJ: Prentice-Hall.

Beldona, S., Morrison, A. M., \& O'Leary, J. (2005). Online shopping motivations and pleasure travel products: a correspondence analysis. Tourism Management, 26(4), 561-570.

Bukhari, S., Ghoneim, A., \& Dennis, C. (2012). Understanding the factors that attract travellers to buy airline tickets online in saudi arabia. In European, Mediterranean \& Middle Eastern Conference on Information System (pp. 619-628).

Bychkov, E. (2014). Chinese and German consumer behaviour when purchasing air tickets online, Unpublished Maters thesis , Berlin: Berlin School of Economics and Law Institute of Management Berlin (IMB).

Chen, F. C. Y. (2007). Passenger use intentions for electronic tickets on international flights. Journal of Air Transport Management, 13(2), 110-115.

Davis, F. D. (1989). Perceived usefulness, perceived ease of use, and user acceptance of information technology. MIS quarterly, 13(3), 319-340.

Davis, F. D., Bagozzi, R. P., \& Warshaw, P. R. (1989). User acceptance of computer technology: a comparison of two theoretical models. Management science, 35(8), 982-1003. 
Diggines, C. (2010). Passenger perceptions and understanding of the low-cost and full-service airline models in South Africa and the implications for service strategy, s.l.: [Online]Availablebfrom:nhttp://www.uom.ac.mu/sites/irssm/papers/Diggines\%20 \%2012.pdf.

Ghana Communication Authority (2017). Telecom Data Subscription, Accra: GCA.

Gupta, A., Su, B. C., \& Walter, Z. (2004). An empirical study of consumer switching from traditional to electronic channels: A purchase-decision process perspective. International Journal of Electronic Commerce, 8(3), 131161.

Ho, C. I., \& Lee, Y. L. (2007). The development of an e-travel service quality scale. Tourism Management, 28(6), 1434-1449.

International Air Transport Association (2013). Airline Industry Forecast 2013-2016, s.l.: IATA.

Guo, J., \& Jaafar, N. I. (2011). A study on consumers' attitude towards online shopping in China. International Journal of Business and Social Science, 2(22), 122-132.

Kaplan, A. M., \& Haenlein, M. (2012). Social media: back to the roots and back to the future. Journal of Systems and Information Technology, 14(2), 101-104.

Kim, L. H., Kim, D. J., \& Leong, J. K. (2005). The effect of perceived risk on purchase intention in purchasing airline tickets online. Journal of Hospitality \& Leisure Marketing, 13(2), 33-53.

Kim, L. H., Qu, H., \& Kim, D. J. (2009). A study of perceived risk and risk reduction of purchasing air-tickets online. Journal of Travel \& Tourism Marketing, 26(3), 203-224.

Kotler, P. \& Keller, K. (2009). Marketing Management (13th edition). New Jersey, NJ:: Prentice-Hall.

Krejcie, R. V., \& Morgan, D. W. (1970). Determining sample size for research activities. Educational and psychological measurement, 30(3), 607-610.

Kwek, C. L., Tan, H. P., \& Lau, T. C. (1970). Investigating the shopping orientations on online purchase intention in the e-commerce environment: a Malaysian study. The Journal of Internet Banking and Commerce, 15(2), 121.

Legris, P., Ingham, J., \& Collerette, P. (2003). Why do people use information technology? A critical review of the technology acceptance model. Information \& management, 40(3), 191-204.

Li, N., \& Zhang, P. (2002). Consumer online shopping attitudes and behavior: An assessment of research. AMCIS 2002 Proceedings, 74.

Llach, J., Marimon, F., del Mar Alonso-Almeida, M., \& Bernardo, M. (2013). Determinants of online booking loyalties for the purchasing of airline tickets. Tourism Management, 35, 23-31.

Mills, J. E., \& Morrison, A. M. (2003). Expanding and Re-Testing E-SAT: An Instrument and structural model for measuring customer satisfaction with travel websites. In Travel and Tourism Research Association Conference.

Motlaq, S. V., Ghodsi, F., Kazemi, M., Motla, T. V., \& Motlaq, M. V. (2012). The Estimation of Customer's Electronic Trust (E-Trust) Toward Airline E-Ticketing in Iran using the Technology Acceptance Model (TAM). Middle Eastern Finance and Economics.

Muller, P., Damgaard, M., Litchfield, A., Lewis, M., \& Hörnle, J. (2011). Consumer behaviour in a digital environment. Policy Department Economic and Scientific Policy, European Parliament, B-1047 Brussels.

Nusair, K., \& Kandampully, J. (2008). The antecedents of customer satisfaction with online travel services: a conceptual model. European Business Review, 20(1), 4-19.

Sam, M. F. M. \& Tahir, M. N. H. (2009). Website quality and consumer online purchase intention of air ticket. International Journal of Basic \& Applied Sciences, 9(10), pp. 20-25.

Shchiglik, C., \& Barnes, S. J. (2004). Evaluating website quality in the airline industry. Journal of Computer Information Systems, 44(3), 17-25.

Toh, R. S., DeKay, C. F., \& Raven, P. (2011). Travel planning: searching for and booking hotels on the internet. Cornell Hospitality Quarterly, 52(4), 388-398.

Yu, S. F. (2008). Price perception of online airline ticket shoppers. Journal of Air Transport Management, 14(2), 66-69.

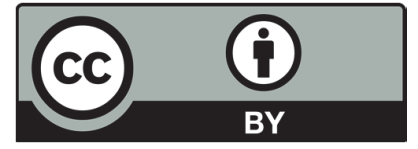

(C) 2018 by the authors; licensee Growing Science, Canada. This is an open access article distributed under the terms and conditions of the Creative Commons Attribution (CCBY) license (http://creativecommons.org/licenses/by/4.0/). 